\title{
Water Coning Prediction: An Evaluation of Horizontal Well Correlations
}

\author{
Anietie Ndarake Okon ${ }^{1}$, Dulu Appah ${ }^{2}$ \\ ${ }^{1}$ Department of Chemical and Petroleum Engineering, University of Uyo, Uyo, Nigeria \\ ${ }^{2}$ Department of Gas Engineering, University of Port Harcourt, Port Harcourt, Nigeria
}

Email address:

anietieokon@uniuyo.edu.ng (A. N. Okon)

\section{To cite this article:}

Anietie Ndarake Okon, Dulu Appah. Water Coning Prediction: An Evaluation of Horizontal Well Correlations. Engineering and Applied Sciences. Vol. 3, No. 1, 2018, pp. 21-28. doi: 10.11648/j.eas.20180301.14

Received: January 30, 2018; Accepted: February 11, 2018; Published: March 14, 2018

\begin{abstract}
Oil production from bottom-water drive reservoirs is characterized by water production related problem - water coning. Most times, horizontal wells are used to attenuate this production challenge. That notwithstanding, overtime, depending on the production rate, water coning is also experienced with horizontal wells. Therefore, several correlations have been developed to predict the critical rate, breakthrough time and water-cut performance after breakthrough in horizontal wells. However, limited studies have evaluated the predictions of these developed water coning correlations. Therefore, an evaluation has been made to predict the various water coning correlations in horizontal wells. The obtained results show that the critical rate directly depends on the stand-off to drainage width and horizontal well length to drainage width ratios. Also, it is shown that the breakthrough time directly depends on the horizontal well length to drainage width ratio. Furthermore, the correlations developed from water-cut data for the prediction of post-water behaviour (i.e., water-cut performance) after breakthrough indicate more proficient water-cut profile than the correlations developed from water-oil ratio. Therefore, to prolong the occurrence of water coning in horizontal wells, the ratios of stand-off to drainage width and horizontal well length to drainage width should be considered to achieve maximum critical oil rate and breakthrough time in bottom-water reservoirs.
\end{abstract}

Keywords: Bottom-Water Reservoir, Water Coning Prediction, Critical Rate, Breakthrough Time, Water-Cut Performance, Horizontal Wells

\section{Introduction}

In the petroleum industry, the use of horizontal well in the production of oil and gas is not limited to increasing the well deliverability, improved well productivity, reduce the number of producing wells, effectively drain the reservoir, among others. The technology is sometimes used as water coning attenuation approach; especially in thin-oil column reservoirs with strong active bottom-water drive. Generally, in strong bottom-water drive reservoirs, oil production from well (s) in these reservoirs lead to changing pressure drawdown around the wellbore, which causes the movement of oil/water interface toward the producing interval. Most times, vertical wells exhibit a large pressure drawdown in the wellbore vicinity than horizontal wells. Horizontal wells provide an option whereby pressure drawdown is minimized and high production rate sustained
[1]. In addition, at low drawdown, horizontal wells can have a larger capacity to produce oil compared to conventional vertical wells. However, the problem of water coning; termed water cresting in horizontal wells, is still experienced in bottom-water drive reservoirs. Therefore, water coning according to Okwananke and Isehunwa [2] is the upward movement of water into the perforations of a producing well. In both vertical and horizontal wells, water coning occur when there is an imbalance of forces between viscous and gravity forces [3]. Azim [4] added that there are essentially three forces: capillary, gravity and viscous, controlling the mechanism of water coning. Thus, the severity of water coning in oil and gas production cannot be undermined, as it results in production related problems like: excessive water production, water disposal challenges, low oil productivity, etc.

The study of water coning phenomenon in reservoir engineering is fundamental as most petroleum reservoirs are 
sandwiched between gas and water zones. The early studies of this phenomenon made reference to the work of Muskat and Wyckoff [5]. This pioneer study led to the development of correlations: critical rate, breakthrough time and postwater behaviour after breakthrough by several authors to predict water coning. Among these correlations, Osisanya et al. [6] mentioned that critical rate is probably the most discussed coning parameter. In horizontal wells, water coning is very complex and difficulty to solve analytically, as the flow geometry is not as simple as the vertical well. However, several studies have been carried out to understand the mechanism of water coning in horizontal wells and some correlations have been developed. Authors like Efros [7], Kracher et al. [8], Giger [9], Chaperon [10], Joshi [11], Yang and Wattenbarger [12], Recham et al. [13], and others have provided critical rate correlations for horizontal wells. On the other hand, Papatzacos et al. [14], Ozkan and Raghavan [15], Bahadori [16], Makinde et al. [17], etc. provide correlations for coning breakthrough time in horizontal wells. For the post-water behaviour (i.e., water-cut performance) after breakthrough Yang and Wattenbarger [12], Souza et al. [18] and Permadi and Jayadi [19] presented correlations for horizontal wells. Unfortunately, there are significant variations in the predictions of the numerous water coning correlations. Inikori [20] maintained that these variations arise mainly due to the approximating assumptions used to simplify the complex mathematical solutions of the two- or three-phase flow in porous media. Therefore, this paper evaluates the various water coning correlations for horizontal wells to assess the most reliable correlation ( $s$ ) for the prediction of this production rate-sensitive phenomenon during oil production in bottom-water drive reservoirs.

\section{Water Coning Mechanism in Horizontal Wells}

In bottom-water drive reservoir, be it vertical or horizontal well, the flow of oil from the reservoir to the well introduces an upward dynamic force upon the fluids [21]. This dynamic (viscous) force, due to wellbore pressure drawdown, causes the bottom water to rise to a certain point at which the dynamic force is balanced by the height of the water beneath that point. Then, as the distance from the wellbore increases the pressure drawdown and the upward dynamic (viscous) force caused by it decreases. This development causes the water-oil contact (WOC) below the oil completion interval to rise toward the perforation. In horizontal wells (as depicted in Figure 1), the mentioned phenomenon is experienced at the heel than the toe of the horizontal well. At low production rate, a stable cone is experienced as the dynamic force offsets the gravity contrast between the oil and water phase [1]. Over time, this contrast between the water and oil cannot offset their mobility differences, then, the water cone becomes unstable and rises towards the well completion.

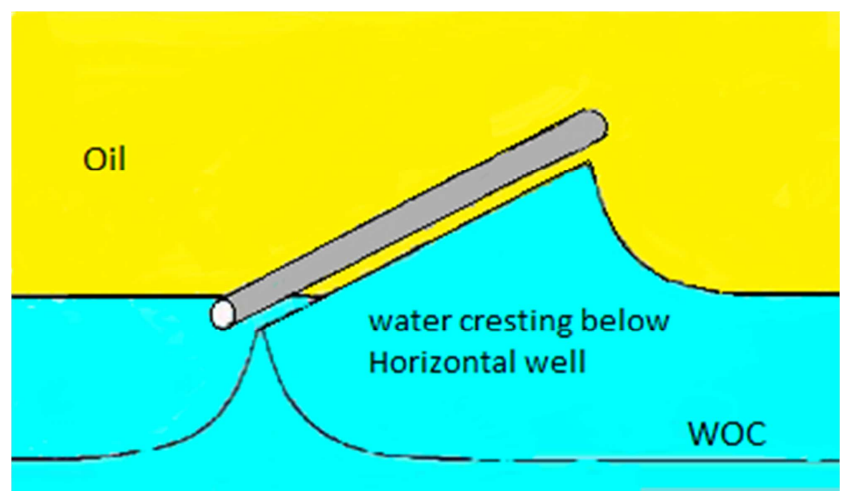

Figure 1. Water Coning in Horizontal Well [22].

According to Karami et al. [23] planning to avoid and/or separate the water produced during water coning takes a long time. As earlier alluded, several correlations have been developed to predict water coning in horizontal wells. These correlations: critical rate, breakthrough time and water-cut performance after breakthrough are developed based on two approaches (i.e., analytical and numerical). Also, Okon et al. [1] added that the assumptions regarding: reservoir types, reservoir parameters and flow types, and the model used are incorporated in these approaches to develop the correlations. For the critical rate, one of the assumptions is that the water cone has risen to a certain height before its breakthrough into the well. Additionally, the analytical approach establishes the critical rate correlations based on the equilibrium conditions of gravity forces and pressure gradients. Practically, producing oil below the critical rate is not economical. Therefore, operating companies often produce at a rate higher than the critical coning rate. Once the production rate exceeds the critical rate, the water cone moves toward the well and subsequently breaks into the wellbore. At this point, knowing the breakthrough time helps to improve well management and extend well life without water production [24]. So far, available correlations to predict horizontal wells breakthrough time are based on analytical and numerical approaches. Currently, there is no analytical solution to estimate water-cut performance after breakthrough in horizontal wells; or even in vertical wells. The available correlations for post-water (water-cut) breakthrough performance predictions are developed based on numerical simulation data. Thus, some of the available correlations to predict water coning in horizontal wells are presented in Tables A1 through A3.

\section{Horizontal Well Correlations Evaluation}

Even though horizontal well technology is one of the water coning attenuation methods, prediction of water coning (cresting) phenomenon in horizontal wells is a necessity to achieve maximum oil production and/or recovery from the reservoir. To evaluate the potentials of these water coning correlations' predictions in horizontal wells, the basic reservoir and fluid properties data were extracted from the 
work of Khalili [22] and Kumar et al. [25]. These extracted water coning correlations presented in Tables A1through A3. data as presented in Table 1 were used to evaluate the various

Table 1. Basic Reservoir and Fluid Properties.

\begin{tabular}{lll}
\hline Reservoir data & & Fluid data \\
\hline Drainage Width $\left(\mathrm{X}_{\mathrm{e}}\right), \mathrm{ft}$ & 2000 & Density of water, $\rho_{\mathrm{w}}\left(\mathrm{lb} / \mathrm{ft}^{3}\right)$ \\
Horizontal permeability, $\mathrm{k}_{\mathrm{h}}(\mathrm{md})$ & 100 & Density of oil, $\rho_{\mathrm{o}}\left(\mathrm{lb} / \mathrm{ft}^{3}\right)$ \\
Vertical permeability, $\mathrm{k}_{\mathrm{v}}(\mathrm{md})$ & 10 & Oil viscosity, $\mu_{\mathrm{o}}(\mathrm{cp})$ \\
Pay zone thickness, $\mathrm{h}(\mathrm{ft})$ & 70 & Water viscosity, $\mu_{\mathrm{w}}(\mathrm{cp})$ \\
Standoff from WOC, $\mathrm{d}(\mathrm{ft})$ & 56 & Oil formation volume factor, $\mathrm{B}_{\mathrm{o}}$ \\
Average reservoir pressure, $\mathrm{P}(\mathrm{psi})$ & 3769 & Water formation volume factor, $\mathrm{B}_{\mathrm{w}}$ \\
Formation porosity, $\varphi$ & 0.32 & end-point oil relative permeability $\left(\mathrm{k}_{\mathrm{ro}}\right)$ \\
Wellbore radius, $\mathrm{r}_{\mathrm{w}}(\mathrm{ft})$ & 0.25 & end-point water relative permeability $\left(\mathrm{k}_{\mathrm{rw}}\right)$ \\
Length of horizontal well, $\mathrm{L}(\mathrm{ft})$ & 1500 & Connate water saturation, $\mathrm{S}_{\mathrm{wc}}$ \\
Half drainage length, $\mathrm{Y}_{\mathrm{e}}(\mathrm{ft})$ & 2000 & Residual Oil Saturation, $\mathrm{S}_{\mathrm{or}}$ \\
Oil production rate, $\mathrm{q}(\mathrm{stb} / \mathrm{day})$ & 1500 & \\
\hline
\end{tabular}

Source: Khalili [22] and Kumar et al. [25].

\section{Results and Discussion}

\subsection{Critical Rate}

For the evaluation of the various critical rate correlations in horizontal wells, two parameters were used to evaluate the critical rate prediction of the various correlations. These parameters are: stand-off to drainage width $\left(\mathrm{d} / \mathrm{X}_{\mathrm{e}}\right)$ and horizontal well length to drainage width $\left(\mathrm{L} / \mathrm{X}_{\mathrm{e}}\right)$. The obtained results as depicted in Figure 2 indicate that Kracher et al. [8], Efros [7], Permadi [26] and Giger [9] correlations have the same profile and close critical rate predictions. However, these correlations' predicted critical rates which were very low compared to the prediction of Ozkan and Raghavan [15] with about $92.74 \mathrm{stb} / \mathrm{d}$ at stand-off to drainage width of about 0.028 . Figure 3 further presents the critical rate against standoff to drainage width results. This result indicates that Chaperon [10], Joshi [11], Yang and Wattenbarger [12], and Recham et al. [13] correlations predict high critical rate; as Recham et al. [13] correlation predicted the highest among these correlations. From the Figures, it is observed that the critical rate increases as the stand-off to drainage width increases for all correlations; except for Joshi [27] correlation which predicts the reverse. This implies that, in horizontal wells, critical rate is stand-off to drainage width dependent. Therefore, it requires consideration during placement of horizontal well to prolong water coning occurrence in bottom-water drive reservoirs.

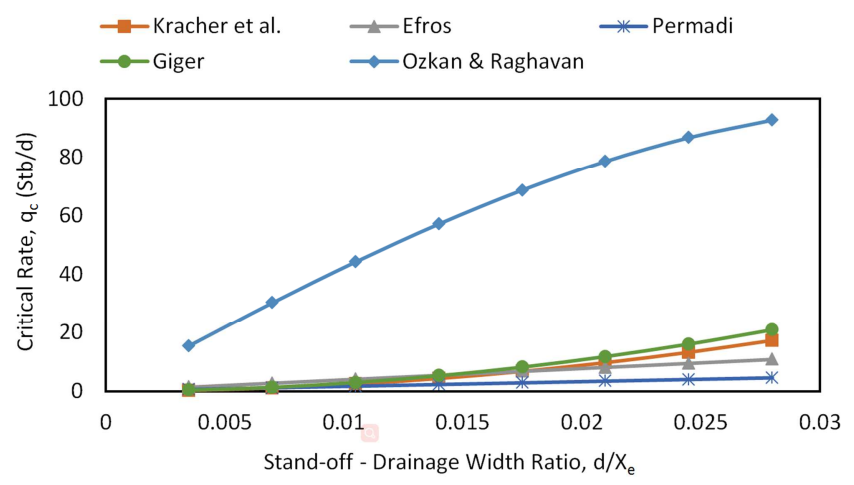

Figure 2. Critical Rate vs. Stand-off-Drainage Width Ratio.

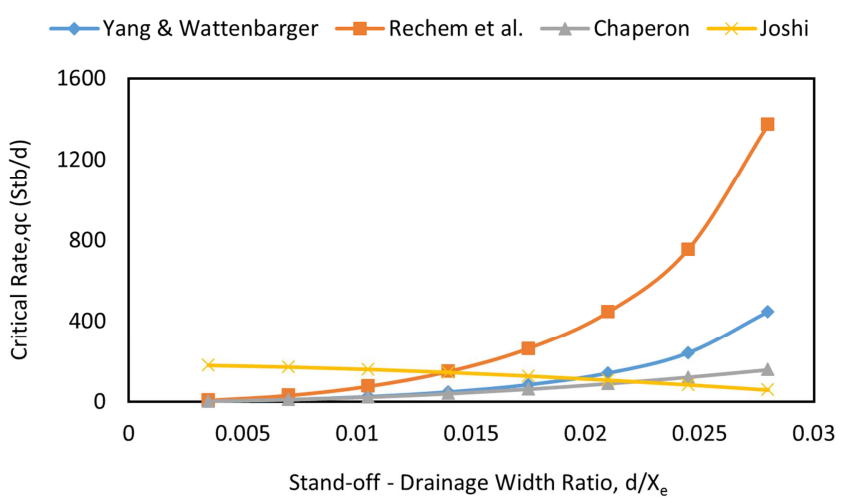

Figure 3. Critical Rate vs. Stand-off-Drainage Width Ratio.

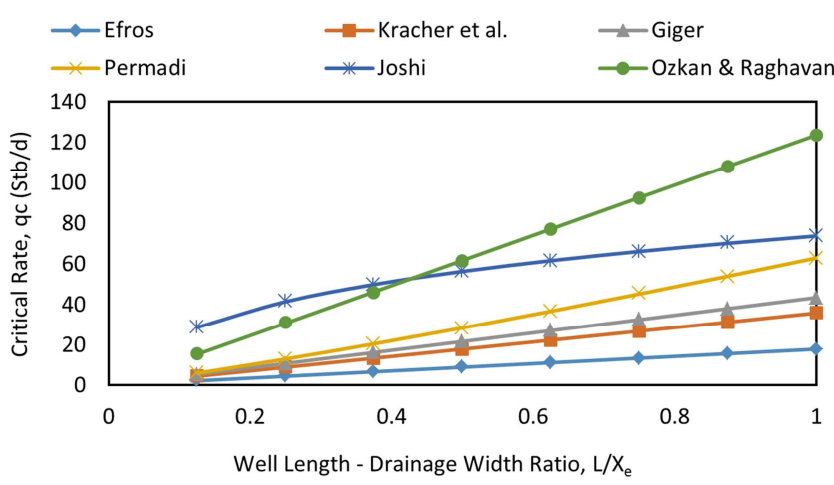

Figure 4. Critical Rate vs. Well Length - Drainage Width Ratio.

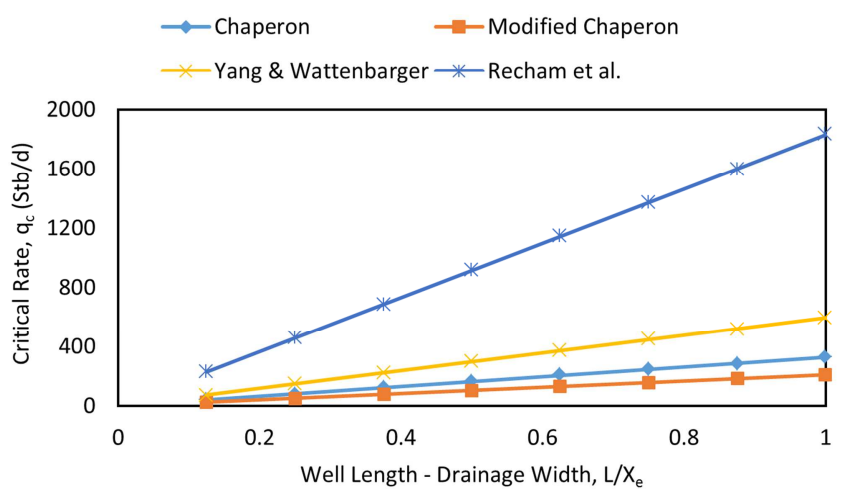

Figure 5. Critical Rate vs. Well Length - Drainage Width Ratio.

On the other hand, Figures 4 and 5 present the critical rate 
against horizontal well length to drainage width $\left(\mathrm{L} / \mathrm{X}_{\mathrm{e}}\right)$ prediction of the various correlations. From the results, it is noted that the critical rate is directly dependent on the well length - drainage width ratio. However, the results further indicate that these correlations: Efros [7], Kracher et al. [8], Giger [9], Permadi [26], Joshi [11] and Ozkan and Raghavan [15] resulted in low critical rate prediction when compared to the predictions of Chaperon [10], modified Chaperon by Joshi [27], Yang and Wattenbarger [12] as well as Recham et al. [13]. Interestingly, almost all the correlations have the same trend of predicting the critical rate against well length to drainage width in horizontal wells. Just like stand-off to drainage width ratio $\left(\mathrm{d} / \mathrm{X}_{\mathrm{e}}\right)$, the obtained results indicate that well length to drainage width $\left(\mathrm{L} / \mathrm{X}_{\mathrm{e}}\right)$ is another factor to be considered in horizontal well placement to suppress early water cone in bottom-water drive reservoirs.

\subsection{Breakthrough Time}

The breakthrough time was evaluated as a function of horizontal well length to drainage width ratio $\left(\mathrm{L} / \mathrm{X}_{\mathrm{e}}\right)$; as presented in Figure 6. From the obtained results, it is observed that all the correlations have the same profile except for Makinde et al. [17] correlation. Also, the various correlations predicted different breakthrough time at the same horizontal well length to drainage width ratio $\left(\mathrm{L} / \mathrm{X}_{\mathrm{e}}\right)$. This variance in the correlations predictions are attributed to the different approaches and assumptions made in the development of the correlations. Furthermore, the result indicates that water coning (cresting) breakthrough time in horizontal well increase as the horizontal well length to drainage width ratio increases. Meaning, the breakthrough time is directly dependent on the horizontal well length to drainage width ratio $\left(\mathrm{L} / \mathrm{X}_{\mathrm{e}}\right)$. Therefore, this observation further supports the use of horizontal well technology to delay water coning tendency in bottom-water drive reservoirs.

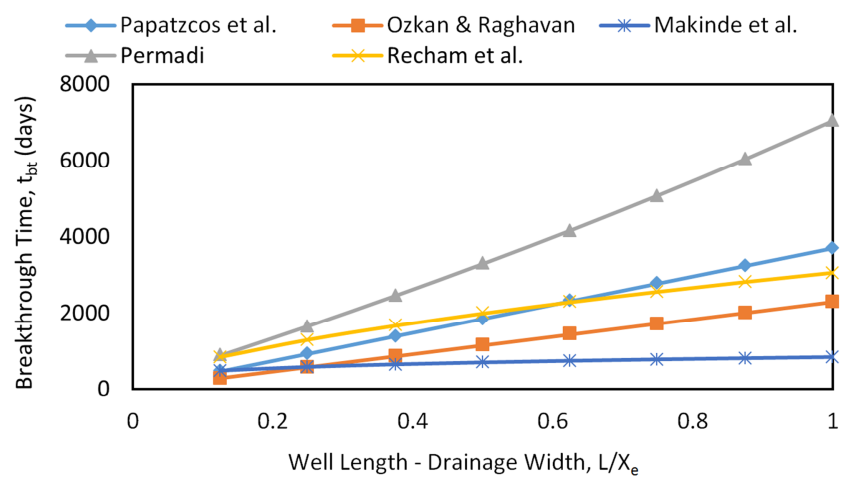

Figure 6. Breakthrough Time vs. Well Length - Drainage Width Ratio.

\subsection{Water-cut After Performance Breakthrough}

Figure 7 presents the different correlations prediction of post-water behaviour (i.e., water-cut performance) after breakthrough in horizontal wells. From the Figure, Yang and Wattenbarger [12] and Souza et al. [18] correlations have the same profile but different predictions of the water-cut performance. That is, Yang and Wattenbarger [12] and Souza et al. [18] correlations predicted water-cut of about $33 \%$ and $95 \%$ respectively after 10.5 years. For Permadi and Jayadi [19] correlation, its prediction was not of a typical water-cut profile; as the obtained water-cut profile was exponential in nature. Meaning, a near steady water-cut profile was not established as the evaluated water-cut performance approaches $1(100 \%)$; as observed in the case of Souza et al. [18] correlation prediction profile.

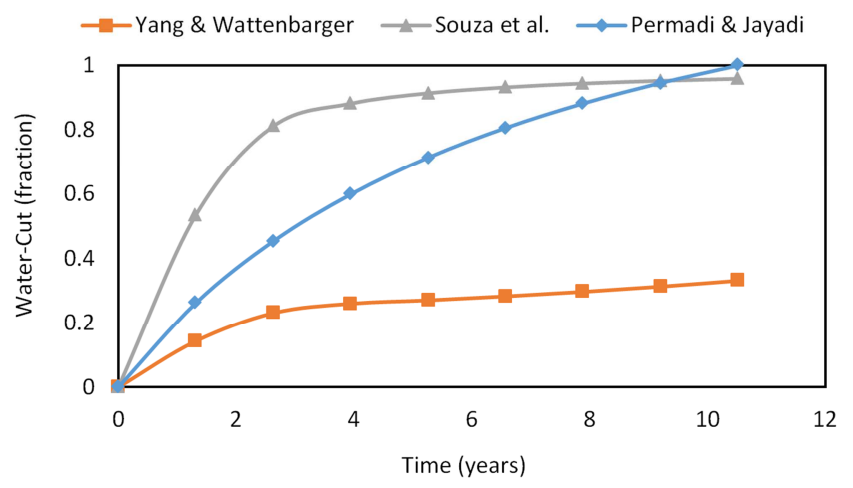

Figure 7. Water-cut Performance after Breakthrough vs. Time.

In summary, this evaluation has put forward the reliability of the various correlations to predict water coning in horizontal wells. The approaches: analytical, empirical, numerical or combined and the assumptions used in the development of the correlation are factors that affect the reliability of its prediction. Thus, most of the various water coning correlations evaluated in this study predicted different values for the water coning parameters: critical rate, breakthrough time and water-cut performance after breakthrough in horizontal wells. Additionally, despite the variance in their predictions, some of the correlations have about the same profile for the water coning parameters in horizontal wells.

\section{Conclusion}

The use of horizontal well technology as water coning (cresting) suppression approach does not completely eliminate this production rate-sensitive phenomenon in bottom-water drive reservoirs. Therefore, the proper prediction of this phenomenon in horizontal wells is of essence. Hence, several authors have developed correlations to predict water coning in horizontal wells based on numerous approaches and assumptions. However, limited works have evaluated the consistency of these correlations to predict coning parameters in horizontal wells. Therefore, this study evaluates the various water coning correlations in horizontal wells, and the following conclusions are drawn:

i. all the correlations predicted different values for the water coning parameters: critical rate, breakthrough and water-cut performance after breakthrough in horizontal wells;

ii. in horizontal wells, critical production rate directly depends on stand-off to drainage width and 
horizontal well length to drainage width ratios, while breakthrough time directly depends on horizontal well length to drainage width ratio; and

iii. also, correlations to evaluate post-water behaviour or water-cut performance after breakthrough developed from water-cut data predict more realistic water-cut profile than correlations from water-oil ratio data.

Therefore, in bottom-water reservoirs with active aquifer, placement of horizontal well should consider stand-off to drainage width as well as horizontal well length to drainage width to achieve optimum critical production rate and breakthrough time.

\section{Nomenclature}

$q_{c}=$ critical rate, $s t b / d$

$\Delta \rho=$ water-oil density difference, $l b / f t^{3}$

$\mu_{o}=$ oil viscosity, $c p$

$\mu_{w}=$ water viscosity, $c p$

$r_{w}=$ wellbore radius, $f t$

$r_{e}=$ drainage radius, $f t$

$r_{w e}=$ effective wellbore radius, $f t$

$r_{e h}=$ horizontal well drainage radius, $f t$

$h=$ pay-zone thickness, $f t$

$A=$ reservoir area, $f t^{2}$

$d=$ stand-off from WOC, $f t$

$k_{v}=$ vertical permeability, $m d$

$k_{h}=$ horizontal permeability, $m d$

$k_{r o}=$ oil relative permeability at $S_{w c}$

$t_{b t}=$ breakthrough time, days
$B_{o}=$ oil formation volume factor, $r b / s t b$

$B_{w}=$ water formation volume factor, $r b / s t b$

$M=$ mobility ratio

$g=$ gravity constant, $\mathrm{ft} / \mathrm{hr^{2 }}$

$\varphi=$ formation porosity, fraction

$\alpha=$ mobility ratio exponent

$h_{a p}=$ height above perforation, $f t$

$h_{b p}=$ height below perforation, $f t$

$h_{w b}=$ breakthrough height (cone height), $f t$

$h_{w}=$ water zone thickness, $f t$

$q_{o=}$ oil production rate $s t b / d$

$q_{c_{D}}=$ dimensionless critical rate

$\lambda_{o}=$ end-point oil mobility, $\mathrm{Pa} / \mathrm{s}$

$X_{D}=$ dimensionless drainage width

$Z_{D}=$ dimensionless cone height

$\left(t_{D}\right)_{b t}=$ dimensionless breakthrough time

$S_{w c}=$ connate water saturation

$S_{o r}=$ residual oil saturation

$X_{e}=$ drainage width, $f t$

$Y_{e}=$ reservoir length parallel to horizontal well, $f t$

$L=$ horizontal well length, $f t$

$\Delta P_{v}=$ pressure drawdown due to viscous effects, $p s i$

$\Delta \gamma=$ difference between hydrostatic gradients of water and oil, $p s i / f t$

$W C=$ water-cut

$W C_{D}=$ dimensionless water-cut

$W O R=$ water-oil ratio

\section{Appendix}

\section{Appendix $A$}

Table A1. Correlations for Water Coning Critical Rate in Horizontal Wells.

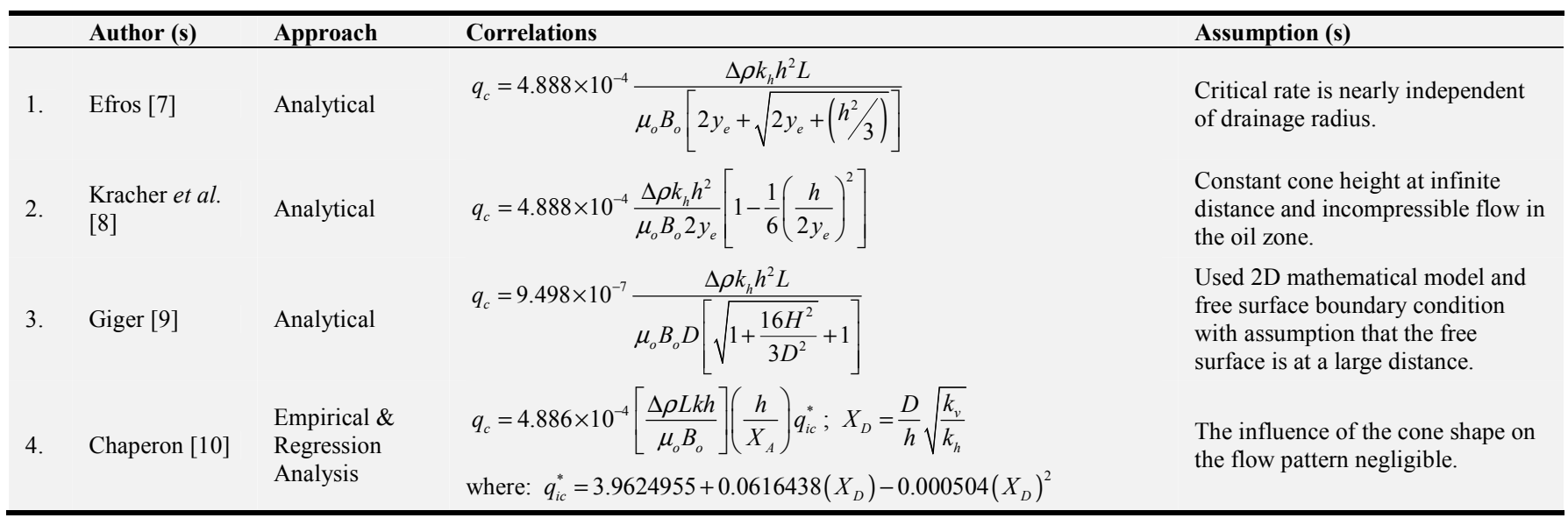




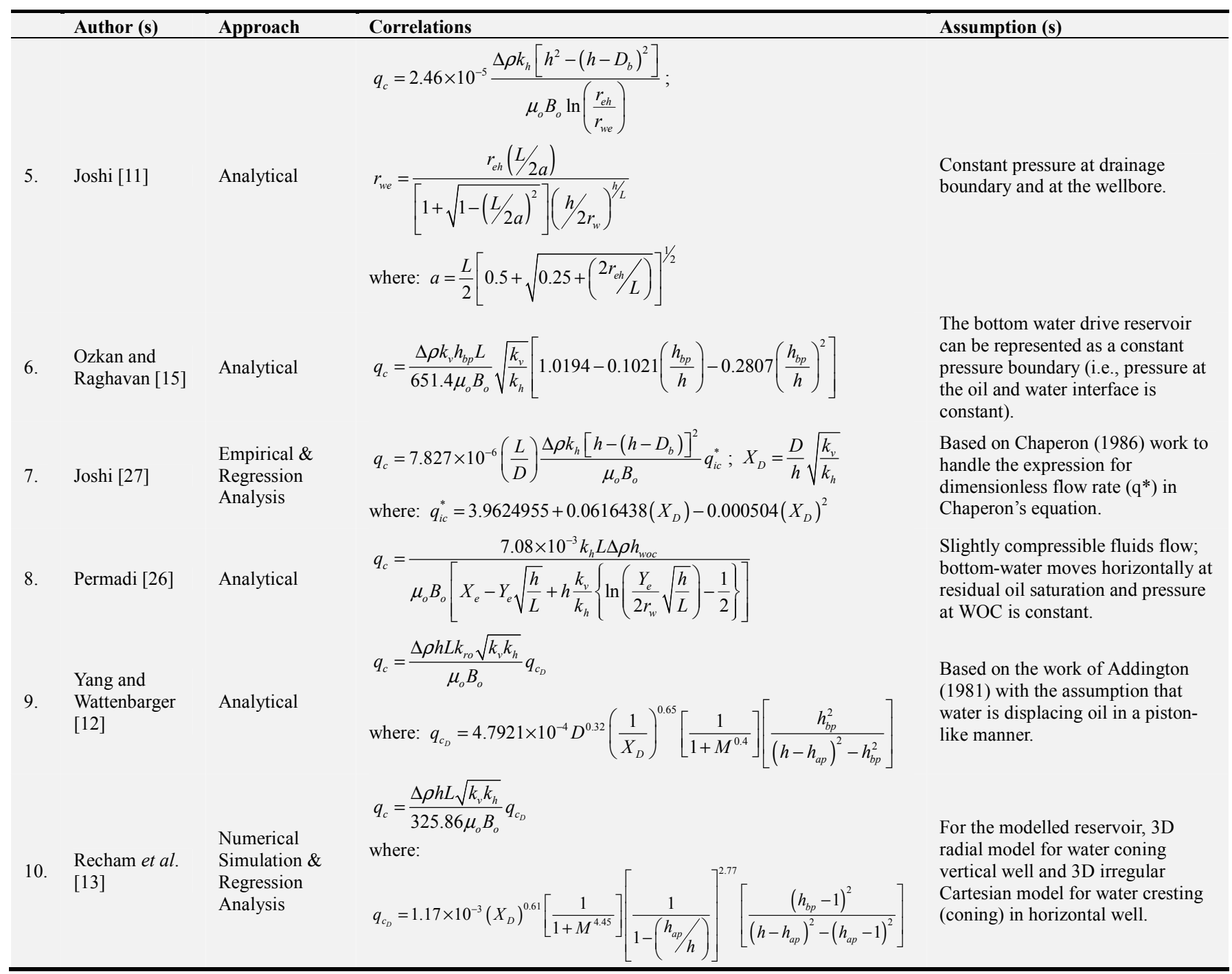

Table A2. Correlations for Water Coning Breakthrough Time in Horizontal Wells.

\begin{tabular}{|c|c|c|c|c|}
\hline & Author (s) & Approach & Correlations & Assumption (s) \\
\hline 1. & $\begin{array}{l}\text { Papatzacos et } \\
\text { al. }[14]\end{array}$ & Semi-analytical & $t_{b t}=1.856 \times 10^{-1} \frac{\varphi h^{2} L \sqrt{k_{v} k_{h}}}{q_{o} B_{o} k_{v}}$ & $\begin{array}{l}\text { moving boundary approach, for } \\
\text { predicting cone evolution in the } \\
\text { transient state }\end{array}$ \\
\hline 2. & $\begin{array}{l}\text { Ozkan and } \\
\text { Raghavan } \\
{[15]}\end{array}$ & Analytical & $t_{b t}=2.226 \times 10^{-1} \frac{k_{h} h^{2} L f}{q_{o} B_{o} k_{v}} \sqrt{\frac{k_{v}}{k_{h}}} ;$ where; $f=\varphi\left(1-S_{w c}-S_{o r}\right)$ & $\begin{array}{l}\text { The bottom water drive reservoir can } \\
\text { be represented as a constant pressure } \\
\text { boundary (i.e., pressure at the oil and } \\
\text { water interface is constant). }\end{array}$ \\
\hline 3. & $\begin{array}{l}\text { Makinde et } \\
\text { al. [17] }\end{array}$ & $\begin{array}{l}\text { Numerical } \\
\text { Simulation \& } \\
\text { Regression } \\
\text { Analysis }\end{array}$ & $t_{b t}=8.98 \times 10^{5}\left[\frac{\varphi^{11.092} A^{0.964} L^{0.264} k_{v}^{0.108} k_{h}^{0.324}}{q^{1.490} h_{a p}^{2.103}}\right]$ & $\begin{array}{l}\text { Initial oil saturation in the aquifer is } \\
\text { zero, the region between initial WOC } \\
\text { and water invaded zone is at residual } \\
\text { oil saturation. }\end{array}$ \\
\hline 4. & Permadi [26] & Analytical & $\begin{array}{l}t_{b t}=\frac{7899\left(\mu_{o}+\mu_{w}\right) \varphi\left(1-S_{o r}\right) h_{w o c}^{2}}{k_{v}\left(\Delta P_{v}-\Delta \gamma h_{w o c}\right)} \\
\left.\text { where; } \Delta P_{v}=141.24 \frac{\mu_{o} q B_{o}\left[X_{e}-Y_{e} \sqrt{\frac{h}{L}}+h \sqrt{\frac{k_{h}}{k_{v}}}\left\{\ln \left(\frac{Y_{e}}{2 r_{w}} \sqrt{\frac{h}{L}}\right)\right\}\right]}{k_{h} h L}\right)\end{array}$ & $\begin{array}{l}\text { Slightly compressible fluids flow; } \\
\text { bottom-water moves horizontally at } \\
\text { residual oil saturation and pressure at } \\
\text { WOC is constant. }\end{array}$ \\
\hline 5. & $\begin{array}{l}\text { Recham et al. } \\
\text { [13] }\end{array}$ & $\begin{array}{l}\text { Numerical } \\
\text { Simulation \& } \\
\text { Regression } \\
\text { analysis }\end{array}$ & $\begin{array}{l}t_{b t}=12657(1+M)^{0.37}\left(\frac{1}{X_{D}}\right)^{0.78}\left(\frac{1}{q_{D}}\right)^{0.62}\left[1-\left(\frac{h_{b p}}{h}\right)^{2}\right]^{0.54}\left[1-\left(\frac{h_{a p}}{h}\right)^{2}\right]^{5.86} \\
\text { where; } q_{D}=\frac{325.86 \mu_{o} B_{o} q_{o}}{\Delta \rho L h \sqrt{k_{v} k_{h}}} ; X_{D}=\frac{X_{e}}{h} \sqrt{\frac{k_{v}}{k_{h}}} ; M=\frac{\mu_{o} k_{r w}}{\mu_{w} k_{r o}}\end{array}$ & $\begin{array}{l}\text { For the modelled reservoir, 3D radial } \\
\text { model for water coning vertical well } \\
\text { and } 3 \mathrm{D} \text { irregular Cartesian model for } \\
\text { water cresting (coning) in horizontal } \\
\text { well. }\end{array}$ \\
\hline
\end{tabular}


Table A3. Correlations for Water-cut Performance after Breakthrough in Horizontal Wells

\begin{tabular}{|c|c|c|c|c|}
\hline & Author (s) & Approach & Correlations & Assumption (s) \\
\hline 1. & $\begin{array}{l}\text { Yang and } \\
\text { Wattenbarger } \\
{[12]}\end{array}$ & $\begin{array}{l}\text { Numerical } \\
\text { Simulation \& } \\
\text { Regression } \\
\text { Analysis }\end{array}$ & $\begin{array}{l}\text { WOR }=0 \text { for } h_{b p}>h_{w b} \\
\log (W O R+0.25)=m\left(h_{b p}-h_{w b}\right)+\log (0.25) \text { for } h_{b p} \leq h_{w b} \\
\text { where; } \\
m=0.004\left[1+2.7496\left(1+M^{0.25}\right) \frac{X_{e}^{0.18}}{h}\left(\frac{1}{X_{D}}\right)^{0.4}\left(\frac{1}{q_{D}}\right)^{0.5}\left(1-\frac{h_{a p}}{h}\right)^{0.3}\right] \\
{\left[\frac{h-h_{a p}}{h_{w b}}\right]^{2}=1+4.7921 \times 10^{-4} X_{e}^{0.32}\left(\frac{1}{q_{D}}\right)\left(\frac{1}{1+M^{0.4}}\right)\left(\frac{1}{X_{D}}\right)^{0.65}}\end{array}$ & $\begin{array}{l}\text { Based on the work of Addington } \\
\text { (1981) with the assumption that } \\
\text { water is displacing oil in a piston-like } \\
\text { manner. }\end{array}$ \\
\hline 2. & $\begin{array}{l}\text { Souza et al. } \\
{[18]}\end{array}$ & $\begin{array}{l}\text { Numerical } \\
\text { Simulation \& } \\
\text { Regression } \\
\text { Analysis }\end{array}$ & $\begin{array}{l}W C=1-\frac{q_{o D}}{q_{D}} \\
\text { where; } \\
q_{o D}=q_{D}\left(\frac{t_{b t D}}{2 t_{D}-t_{b t D}}\right)^{m} ; t_{D}=\frac{\Delta \rho g \lambda_{o} k_{v} t}{\varphi h_{o}} ; \text { and } t_{b t D}=t_{b t D}^{0} e^{-\alpha \Delta Z_{D}} ; \\
\Delta Z_{D}=0.005 \text { for } m=0.50 ; \alpha=2.9727 \text { and } t_{b t D}^{0}=1.6310\end{array}$ & $\begin{array}{l}\text { Homogeneous reservoir with } \\
\text { constant viscosity with negligible } \\
\text { capillary effects and under constant } \\
\text { total production rate. }\end{array}$ \\
\hline 3. & $\begin{array}{l}\text { Permadi and } \\
\text { Jayadi [19] }\end{array}$ & $\begin{array}{l}\text { Numerical } \\
\text { Simulation \& } \\
\text { Regression } \\
\text { Analysis }\end{array}$ & $\begin{array}{l}W C=\frac{1}{\frac{q_{o}}{q_{w}} \frac{B_{w}}{B_{o}}+1} \\
\text { where; } \frac{q_{w}}{q_{o}}=0.025 q_{t}^{0.23}(M)^{0.45}\left(\frac{X_{e} Y_{e}}{d L}\right)^{0.503}\left(\frac{k_{v}}{k_{h}}\right)^{0.14}\left(\frac{h_{w}}{d-h_{w}}\right)\end{array}$ & $\begin{array}{l}\text { Reservoir pressure at the lateral } \\
\text { boundary is constant throughout the } \\
\text { producing life of the well. Steady- } \\
\text { state flow and negligible effects of } \\
\text { gravity forces, capillary forces, } \\
\text { wellbore friction losses etc. }\end{array}$ \\
\hline
\end{tabular}

\section{References}

[1] Okon, A. N., Appah, D. and Akpabio, J. U. (2017). Water Coning Prediction Review and Control: Developing an Integrated Approach. Journal of Scientific Research and Reports, Vol. 14, No. 4, pp. 1-24.

[2] Okwananke, A. and Isehunwa, S. (2008). Analysis of Water Cresting in Horizontal Wells. Paper presented at the $32^{\text {nd }}$ Annual Society of Petroleum Engineers International Conference and Exhibition held in Abuja, Nigeria, 4-6 August.

[3] www.petrowiki.org/Water_and_gas_coning. Accessed $10^{\text {th }}$ May, 2017.

[4] Azim, R. A. (2016). Evaluation of Water Coning Phenomenon in Naturally Fractured Oil Reservoirs. Journal of Petroleum Exploration, Production and Technology, Vol. 6, pp. 279-291.

[5] Muskat, M. and Wyckoff, R. D. (1935). An Approximate Theory of Water Coning in Oil Production. Petroleum Development and Technology in Transactions of American Institute of Mining and Metallurgical Engineers, Vol. 114, pp. 144-163.

[6] Osisanya, S. O., Recham, R. and Touami, M. (2000). Effects of Water Coning on the Performance of Vertical and Horizontal Wells - A Reservoir Simulation Study of Hassi R' Mel Field, Algeria. Paper presented at Canadian International Petroleum Conference held at Calgary, Alberta, Canada, 4-8 June.

[7] Efros, D. A. (1963). Study of Multiphase Flows in Porous Media. Gastoptexizdat, Leningrad.

[8] Karcher, B., Giger, F. and Combe, J. (1986). Some Practical Formulas to Predict Horizontal Well Behaviour. Paper presented at Society of Petroleum Engineers $61^{\text {st }}$ Annual
Conference held in New Orleans, Louisiana, 5-8 October.

[9] Giger, F. M. (1986). Analytic Two-Dimensional Models of Water Cresting before Breakthrough for Horizontal Wells. Paper presented at Society of Petroleum Engineers Annual Technical Conference and Exhibition held in New Orleans, Louisiana, 16-19 September.

[10] Chaperon, I. (1986). Theoretical Study of Coning Toward Horizontal and Vertical Wells in Anisotropic Formations: Subcritical and Critical Rates. Society of Petroleum Engineers, SPE Paper 15377.

[11] Joshi, S. D. (1988). Augmentation of Well Productivity using Slant and Horizontal Wells. Journal of Petroleum Technology, pp. 729-739.

[12] Yang, W. and Wattenberger, R. A. (1991). Water Coning Calculation for Vertical and Horizontal Wells. Paper presented at the $66^{\text {th }}$ Annual Technical Conference and Exhibition of the Society of Petroleum Engineers held in Dallas, Texas, 6-9 October.

[13] Recham, R., Osisanya, S. O. and Touami, M. (2000). Effect of Water Coning on the Performance of Vertical and Horizontal Wells - A Reservoir Simulation Study of Hassi R'mel Field, Algeria. Paper presented at Society of Petroleum Engineers/Petroleum Society of Canadian Institute of Mining, Metallurgy and Petroleum International Conference on Horizontal Well Technology held in Calgary, Alberta, Canada, 6-8 November.

[14] Papatzacos, P., Herring, T. M., Martinsen, R. and Skjaeveland, S. M. (1989). Cone Breakthrough Time for Horizontal Wells. Paper presented at Annual Technical Conference and Exhibition held in San Antonio, Texas, 8-11 October.

[15] Ozkan, E. and Raghavan, R. A. (1990). A Breakthrough Time Correlation for Coning toward Horizontal Wells. Paper presented at Society of Petroleum Engineers Europeans Conference held in The Hague, Netherlands, 22-24 October. 
[16] Bahadori, A. (2010). Determination of Well Placement and Breakthrough Time in Horizontal Wells for Homogeneous and Anisotropic Reservoirs. Journal of Petroleum Science and Engineering, Vol. 75, No. 1-2, pp. 196-202.

[17] Makinde, F. A., Adefidipe, O. A. and Craig, A. J. (2011). Water Coning in Horizontal Wells: Prediction of PostBreakthrough Performance. International Journal of Engineering and Technology, Vol. 11, No 1, pp. 173-185.

[18] Souza, A. L. S., Arabi, S. and Aziz, K. (1997). A Practical Procedure to Predict Cresting Behaviour in Horizontal Wells. Paper presented at the $5^{\text {th }}$ Latin American and Caribbean Petroleum Engineering Conference and Exhibition held in Rio de Janeiro, Brazil, 30 August-3 September.

[19] Permadi, P. and Jayadi, T. (2010). An Improved Water Coning Calculation for Horizontal Wells. Paper presented at Society of Petroleum Engineers/Russian Oil and Gas Technical Conference held in Moscow, Russia, 26-28 October.

[20] Inikori, S. O. (2002). Numerical Study of Water Coning Control with Downhole Water Sink (DWS) Well Completions in Vertical and Horizontal Wells. Unpublished Ph.D. Dissertation Submitted to the Graduate Faculty of the Louisiana University.

[21] El-Gogary, A. F., El-Masry, H. H., Kortam, M. M. and ElRayek, H. R. (2015). Innovative Water Coning Techniques for Horizontal Wells in Isotropic Reservoirs - Successful Case History from Belayim Field. Paper presented at Society of
Petroleum Engineers North Africa Technical Conference and Exhibition held in Cairo, Egypt, 14-16 September.

[22] Khalili, A. (2005). A Review of Critical Coning Rate Correlations and Identifying the most Reliable Equation. Unpublished M.Sc. Dissertation submitted to the School of Petroleum Engineering, University of New South Wales.

[23] Karami, M., Manshad, A. K. and Ashoori, S. (2014). The Prediction of Water Breakthrough Time and Critical Rate with a New Equation for an Iranian Oil Field. Journal of Petroleum Science and Technology, Vol. 32, No. 2, pp. 211-216.

[24] Wagenhofer, T. and Hatzignatiou, D. G. (1996). Optimization of Horizontal Well Placement. Paper presented at Society of Petroleum Engineers Western Regional meeting held in Anchorage, Alaska, 22-24 May.

[25] Kumar, M., Sharma, P. and Gupta, D. K. (2017) Sensitivity Study of Horizontal Length, Offset from Water Oil Contact and Withdrawal Rate of Horizontal Well in Bottom Water Drive Reservoir. Journal of Petroleum Exploration, Production and Technology. doi.10.1007/s13202-0170348-9.

[26] Permadi, P. (1995). Practical Method to Forecast Production Performance of Horizontal Wells. Paper presented at Society of Petroleum Engineers Asia Pacific Oil and Gas Conference held in Kuala Lumpur, Malaysia, 20-22 March.

[27] Joshi, S. D. (1991). Horizontal Well Technology. PennWell Books, Tulsa, Oklahoma, USA. pp. 251-267. 